\title{
Evaluation of Bacterial and Fungal Diseases of the Oil Palm (Elaeis guineensis Jacq) in Pamol Plantations, Ndian Division, Southwest Region, Cameroon
}

\author{
T. T. Oben ${ }^{1}$, O. Oguntade ${ }^{2}$, A. E. Egbe ${ }^{1,4}$, A. A. Mbah ${ }^{1}$, and H. I. Becke ${ }^{1,3}$ \\ ${ }^{1}$ Department of Agronomic and Applied Molecular Sciences, Faculty of Agriculture and \\ Veterinary Medicine, University of Buea, Southwest Region, Cameroon \\ ${ }^{2}$ International Institute of Tropical Agriculture (IITA), PMB 5320, Ibadan, Nigeria \\ ${ }^{3}$ Cameroon Development Corporation (CDC), PMB 305, Limbe, Cameroon \\ ${ }^{4}$ Department of Plant Science, Faculty of Science, University of Buea, Cameroon \\ *Corresponding author
}

\section{A B S T R A C T}

The oil palm is of high economic value due to its palm oil, palm kernel oil and palm wine liquor. Yield of this crop remains low and among the limiting factors, fungal and bacterial diseases are of utmost importance. This study aimed to identify fungal and bacterial diseases of the oil palm, their incidence and distribution in Ndian Division, Cameroon. In 2018, ten plantations at two locations (Kokundu and Lipenja) in Ndian

\section{Keywords}

Fungi, bacteria, disease, incidence, distribution, oil palm

Article Info

\section{Accepted:}

15 June 2021

Available Online: 10 July 2021
Division were surveyed for fungal and bacterial diseases infecting the oil palm. 10 symptomatic and 2 asymptomatic samples of plant parts were collected randomly from each plantation, cultured and identified using their standard protocols. Results indicated that 10 fungi and 3 bacteria were isolated from the 120 plant samples. $38.2 \%$ of samples had fungi which include Botryodiplodia theobromae (BT), Cercospora sp., Colletotrichum gleosporiodes, Curvularia lunata, Corynosporium sp. Fusarium oxysporium, Fusarium verticilioides, Ganoderma boninensis, Penicillium sp. Trichoderma sp. and $21.8 \%$ bacteria; Bacillus cereus, Bacillus substilis, Xanthosomas sp. Fusarium oxysporium was the most abundant with incidence between $3.3 \%$ to $35 \%$ while Bacillus cereus was the most abundant bacterium with incidence ranged between $5 \%$ to $21.6 \%$. Corynosporiun sp. and Trichoderma sp. were absent in Kokundu while BT and Cercospora sp. were not identified in Lipenja. Mixed infection was noted in 22 samples with 17 having 2 and 5 with 3. Latent infection with BT, Curvularia sp. and Bacillus substilis was noticed in $20 \%$ of the asymptomatic samples. This study has established the occurrence of 10 fungi and 3 bacteria infecting oil palm in Ndian Division, Cameroon with Fusarium oxysporium and Bacillus cereus being the most abundant fungus and bacterium respectively.

\section{Introduction}

The oil palm (Elaeis guineensis Jacq) is an Aracaceae and a perennial monoecious plant with trimerous flowers (Kinge et al., 2019) that originated in West Africa (Khairudin and Chong, 2008). It is a Cocoideae, having 225 genera with over 2600 species (Nchanji et al., 
2014) and one of the most important because it produces the following: palm oil, palm kernel oil and palm wine liquor (Idris and Ariffin, 2004; Nkongho et al., 2014). The palm oil is a cholesterol-free vegetable oil and this plant is the most efficient oil bearing crop in the world requiring only 0.26 ha of land to produce one tonne of oil where as soybean and sunflower may use up to 2.22 ha and 1.56 ha respectively to produce the same (Herdis et al., 2020; MPOC, 2017).

The area where oil palm cultivation is concentrated is around the equator on Latitude $10^{0}$ North and South (Dubos et al., 2019). It is produced in 20 countries and consumed in 130 countries making its growth output to exceed those of other oils and thus becoming the fastest growing edible oil in the last 40 years (Chin Fah Kui, 2005). More than 14 million hectares of oil palm have been planted across the tropics. The main producers in Africa are Nigeria, DRC, Ghana and Ivory Coast though Africa's contribution to global palm oil supplies dropped from $77 \%$ in 1961 to $4 \%$ in 2014 but still holding 4.5 million hectares of world's total oil palm cultivated area across climatically suitable regions of West and Central Africa (Elsa et al., 2019). Cameroon currently produces about 465,000 tonnes annually on 200,000 ha and the $12^{\text {th }}$ largest producer in the world (USDA, 2020).

Oil palm production in Cameroon is stratified in three sectors: The smallholders $(\mathrm{SH})$ that used to be in contract with agro-industries, a traditional independent artisanal sector and most importantly, the agro-industrial sector (Nchanji et al., 2015). Among the agroindustries that produce oil palm, the Cameroon Development Corporation, Socapalm and Pamol Plantations Plc are most important with the latter occupying 12,000 ha and being the third largest producer. In the cultivation of many crops in agriculture whether in large plantations or small farms, pests and diseases prevent normal healthy growth and cause significant reduction in crop yield and quality (Gate Fee Chung, 2012). Different parts of the plant including roots, stem, fronds, influorescence, fresh fruit bunches are infected and also, their damages affect growth of seedlings in the nursery. Oil palm diseases can be caused by fungi, bacteria, nematode, parasitic plants and phytoplasmas. Some of them have been reported from many oil palm producing countries like the basal and upper stem rot or Ganoderma butt rot disease caused by Ganoderma boninense which is the most severe oil palm disease in Indonesia, Malaysia and has also been destroying plants in Africa, Papaua New Guinea, Columbia and Thailand (Chaninun, et al., 2013). Fusarium wilt disease caused by Fusarium oxysporium is another disease of high importance in West Africa especially in Nigeria and Cameroon (Mih et al., 2015). Turner (1981) documented over 60 diseases and disorders of the oil palm from around the world but only few studies of oil palm diseases in Cameroon exist at present (Mih et al., 2015; Bakoume et al., 2017). The most important among them are those caused by fungi and bacteria that inhibit growth, reduce yield and fruit quality are scanty. Therefore, the effective and efficient management of diseases is very important to ensure healthy growth of oil palm and to maximize crop yield by achieving high oil yield per hectare. Monitoring and surveillance of disease occurrence and their geographical distribution are the basis of integrated management of oil palm plantations (Chaninun et al., 2013).

The objective of this study is to provide updated information in identifying the fungal and bacterial diseases infecting the oil palm, their incidence and geographical distribution in Ndian Division, Cameroon, so that appropriate management strategies can be developed. 


\section{Materials and Methods}

\section{Study area}

A survey was carried out in Kokundu and Lipenja plantations located in Ekondo-Titi Sub-division, Ndian Division of the South West Region of Cameroon. This sub-division is about $50 \mathrm{~km}$ West of Kumba, the main town in Meme Division. Within Ndian Division, Ekondo Titi is bound in the North by Mundemba, the headquarters of the Division, to the West and South by the coastal districts of Kumbo-Itindi and Bamusso respectively and to the East by Meme Division. The area is about $6,165 \mathrm{Km}^{2}$, has an equatorial maritime climate and a dominant lowland topography. It lies between Latitude $4^{0} 17^{\prime}-5^{\circ} 26^{\prime}$ and Latitude $8^{0} 35^{\prime}-9^{0} 26^{\prime}$ with an altitude of $1,764 \mathrm{~m}$ above sea level (Kimengsi and Lambi, 2015). Rainfall is ranged between $2,500 \mathrm{~mm}$ $4,000 \mathrm{~mm}$ with maximum between July and October, mean annual temperature between $16^{\circ} \mathrm{C}$ and $26^{\circ} \mathrm{C}$ and soil types include: the dark brown alluvial, lateralitic and silty alluvium soils which are good for plantation agriculture especially the oil palm and cocoa (BUCREP, 2010) (Figure 1).

\section{Field inspection and collection of samples}

The survey was carried out in two major oil palm locations; Kokundu and Lipenja of Pamol Plantations Plc. Ten oil palm plantations of each about 14 ha where surveyed from March-April, 2018 for fungal and bacterial diseases infecting them. In each field, stem, root and leaf samples of 12 plants (10 symptomatic and 2 asymptomatic) showing signs and symptoms such as bassidiocarp, rots, wilt, orange leaf spots and symptomless ones were collected randomly and put in labeled polythene zip-lock bags (symptom type, field location and collection date) and transported following quarantine regulations to the International Institute of
Tropical Agriculture (IITA), Ibadan, Nigeria for laboratory analysis. At the laboratory, samples were kept in a cold room until when needed for culturing, isolation and identification using diagnostic keys of Rayner (1970); Hawsksworth et al., (1995) and Kirk et al., (2001).

\section{Sterilization of laboratory materials and preparation of growth media}

Detergents were used to wash glassware for the experiment. Inoculation needles, cork borers and scalpels were dipped into $70 \%$ ethanol and flamed to red hot using a Bunsen flame to effect sterilization. Glassware like beakers, pipettes agar plates were sterilized by heating at $120^{\circ} \mathrm{C}$ for an hour in hot air oven while the laminar flow Hood was cleaned with cotton wool soaked in $70 \%$ ethanol. The UVlight of the lamina flow hood was put on for at least 2 hours and put off before plating of the various samples in semi-solidified agar. Media including Potato dextrose agar, nutrient agar, bacto-agar, carnation leaf agar were suspended individually in one litre conical flask containing distilled water in a water bath and heated for 20 minutes at $50^{\circ} \mathrm{C}$ and later autoclaved at $121^{\circ} \mathrm{C}$ for 20 minutes to effect sterilization before they were cooled and stored at $4^{\circ} \mathrm{C}$ in a refrigerator until when needed.

\section{Bacteria Isolation}

Six labeled Petri-dishes were used for samples collected from each field. Plant materials were washed in tap water and surface sterilized in $5 \%$ sodium hypochloride solution for 3 minutes.

They were rinsed later in sterile distilled water before they were cut aseptically into small pieces of $2 \mathrm{~mm}^{2}$ and placed in Petri dishes containing distilled water. These pieces were macerated with a sterile scalpel blade, and the 
suspensions streaked on nutrient agar. These were incubated for 48 hours and growth observed was purified twice by streaking on fresh nutrient agar. The resultant pure cultures were used for identification tests.

\section{Bacterial Identification Studies}

The following tests were carried out in order to characterize bacteria using the protocol described by Schaad et al., (2001) except otherwise stated

\section{Gram Staining}

In this assay, the reagents used were less than a year old with iodine put in a brown container to prevent decolorization and loss of strength. A thinly spread bacterial film on a clean glass slide was air-dried and the underside lightly flamed twice so as to fix bacteria on the slide.

The smear was flooded on crystal violet solution for a minute and washed in tap water. This was flooded in with iodine solution and allowed to stand for one minute and later washed. Acetone was poured on the slide to have the iodine decolorized and rinsed within 10 seconds. Safranin solution was added as a counter stain for 1 minute and washed, blotted dry before examination under the microscope

\section{Spore Determination (Gerhardt, 1981)}

A colony of bacteria growing on agar medium was suspended in a drop of water on a slide and air dried. Slide was flooded with 5\% (w/v) aqueous malachite green and stained for 10 minutes.

It was then washed thoroughly under running water and dried briefly. This was later counter stained by flooding slide with $0.5 \%(\mathrm{w} / \mathrm{v})$ aqueous safranin for 15 seconds. It was thoroughly rinsed with water and blotted dry. Cells were observed at $40 \mathrm{X}$.
Anaerobic growth (Hugh and Leifson medium) (Schaad et al., 2001)

In this assay, the following reagents were used: Peptone $2.0 \mathrm{~g}$; $\mathrm{NaCl} 5.0 \mathrm{~g} ; \mathrm{KH}_{2} \mathrm{PO}_{4} 0.3$ g; Agar $3.0 \mathrm{~g}$; Bromothymol blue $3.0 \mathrm{~g}$; (1\% aqueous solution). Ingredients were dissolved and the $\mathrm{P}^{\mathrm{H}}$ adjusted to $7.1 .5 \mathrm{ml}$ of basal medium was added to $13 \mathrm{~cm}$ diameter test tubes and sterilized at $121^{\circ} \mathrm{C}$ for 20 minutes. A $10 \%$ aqueous solution of glucose was sterilized by filtration. Two tubes were inoculated with each strain of the organism and one test tube was covered with a layer of sterile melted Vaseline and paraffin to a depth of about $5 \mathrm{~mm}$.

Bacteria colony growth at 33 or $40^{\circ} \mathrm{C}$ (Schaad et al., 2001)

Culture was grown overnight in $10 \mathrm{ml}$ of liquid (Nutrient-Brooth Yeast extract agar (NBY) in a $25 \mathrm{~cm}$ diameter test tube on a slanted rack on a rotary shaker at $25-27^{\circ} \mathrm{C}$. $50 \mu 1$ was removed and added to a new tube of NBY and incubated at $40^{\circ} \mathrm{C}$ on a rotary shaker. Growth was recorded after 24 hours

\section{Urease test}

The concept behind this test is that ammonia is formed when urea is hydrolysed by the enzyme urease. The protocol of Cappuccino and Sherma (1983) was used as follows. About $5 \mathrm{ml}$ of Christenson medium was put into sterile $5 \mathrm{~cm}^{3}$ diameter test tubes and allowed to solidify in a slope. The test tubes were inoculated with the isolate and placed in a shaker for 24 hours at $28^{\circ} \mathrm{C}$. A control tube contained only the basal medium without urea.

\section{Oxidase test}

24-hour-old cultures were grown on NGA and a small loopful of the inoculums was rubbed on a filter paper impregnated with $1 \%(\mathrm{w} / \mathrm{v})$ 
acqueous tetramethyl-p-phenylenediamine dihydrochloride solution that was freshly made. A platinum loop was used since traces of iron could catalyse the oxidation of the phenylenediamine compound.

\section{Colony coloration and consistency on Yeast Dextrose Agar}

Bacterial colony was streaked onto agar plate and incubated at $30^{\circ} \mathrm{C}$ before observation on microscope

\section{Fluorescent and diffusible non-fluorescent pigments on King Broth Medium (KB)}

Culture was streaked onto agar plate and incubated at $25^{\circ} \mathrm{C}$. After $48 \mathrm{~h}$, it was observe for non-fluorescent pigments under normal light and in dark with long wave length UV light $(366 \mathrm{~nm})$ for fluorescent pigment.

\section{Flagella or motility test}

Here bacterium was prepared by growing it on agar plates of YDC at $27^{\circ} \mathrm{C}$ for $48 \mathrm{~h}$. Erwinia carotovora was used and its polar species $P$. marginalis used as control.

A cloudy suspension was formed by adding $1.0 \mathrm{ml}$ of distilled water to butt of slant. The slant was not mechanically agitated and a loopful of distilled water was put on an alcohol-cleaned slide.

After this a loopful of bacteria suspension was placed just by touching the distilled water and the slides were allowed to air dry.

After this staining procedure followed whereby the smear with reagent $A$, was covered for 4 minutes then rinsed in distilled water then reagent $\mathrm{B}\left({ }_{\mathrm{PH}} \mathrm{H}\right.$ 10.0) for about 30 seconds and was immediately washed in distilled water. This was air dried and examine under oil immersion

\section{Isolation and Identification Of Fungal Pathogens}

\section{Source of plant material and isolation}

Equipment used was sterilized and growth media prepared as described in bacterial isolation. Same plant portions were used for bacterial and fungal isolation. About $2 \mathrm{~mm}^{2}$ of plant part was cut using a sterile scalpel from the leading edge of the symptomatic area, where it is known that fungal growth is most active. After washing with tap water, it was surface sterilized in $1 \%$ sodium hypochloride solution for 5 minutes and rinsed in distilled water 4 times at 1 minute per wash in 9diameter Petri dishes containing distilled water and thereafter, 4 pieces of plant material was plated separately on Potato dextrose agar.

Fusarium isolates were identified by streaking sample portions on Peptonepentachloronitrobenzene (PPA) a selective medium for isolation of Fusarium sp. and the others fungi, sub-cultured in potato dextrose agar (PDA). Single spores were plated and incubated on water agar for a day; in complete medium for seven days and on carnation leaf agar for 2 weeks. Pure fungal cultures raised were identified based on colony morphology and microscopic examination of their spores (Leslie and Summerell, 2001).

All microscopic examination of fungal isolates was done by teasing a small portion of the material with a sterilized needle on a slide using lactophenol and covering with a cover slip before mounting on a microscope. Subculturing was done by cutting a $2 \mathrm{~mm}^{2}$ portion of growing mycelium using a sterile needle and placing it centrally on a fresh plate containing PDA. All magnifications was done on X100 and or X400 depending on clarity of the micrographs. Colony morphology, growth rates and presence of pigments was identified on PDA alongside microconidia (shape, size, 
number of septa, shape of basal and apical cells, presence of chlamydiospores, conodiogenous cells (monophylides and polyphylides) and spore type. Description of microconidia was done aided by the use of the mycological dictionary of Kirk et al., (2001), while Rayners morphological chart (1970) and Hawsksworth et al., (1995) terminologies were used in describing colony colours and nature of their edges, zonation and texture of aerial mycelium.

\section{Data Analysis}

Data obtained was subjected to descriptive analysis and results were presented as tables, frequency distribution, and percentages.

Disease incidence for each field was calculated using the formula: Total number of each isolate of fungus or bacterium/ Total number of collected samples per location expressed as a percentage (1).

Distribution $=$ Number of each pathogen isolated of the total samples collected per locality (2).

\section{Results and Discussion}

\section{Symptoms of bacteria and fungal diseases on oil palm plants}

Foliar symptoms observed on leaves was yellowish spots with central brownish points that enlarge to dark brown spots; browning of the leaflets spreading from the leaf tip with sharply defined boundaries between healthy and diseased tissues. The yellowish and brownish discoloration of leaf in the middle of crown spreads to neighbouring leaves.

For the stem symptoms, the presence of fruiting bodies on the base of the stem near the ground, rot on bottom and top portions of oil palm stem as seen in Plates $1(\mathrm{~A}-\mathrm{K})$

\section{Bacteria isolation and identification}

Growth of bacterial cultures was observed three days after inoculation in vial tubes used to test isolates for oxidative and fermentation reactions and in the fourth day, the colours in all the tubes changed from green to yellow. Cream coloured bacterial colony changed from purple to red after adding crystal violet, iodine, acetone and safranin solutions and on microscopic examination under oil immersion. Motility test showed about $80 \%$ of cells darting from one point to another when viewed on the microscope and the others either rested in one position or vibrate gently and also, showed the flagella stained darkbrown to black on a light background.

None of the isolates fluorescent after a freshly streaked culture incubated for 48 hours was observed under normal light and in dark cupboard with long wavelength ultraviolet light except Pseudomonas (characteristics often associated with Pseudomonas sp.). For spore determination, bacillus cells stained red and spores green. There was no colour change in tubes inoculated with bacteria cultures after being covered with Vaseline and paraffin. This was recorded as negative for anaerobic growth (fermentation). Oxidase test showed that the strain was rated oxidase-positive since a purple colour developed within 10 seconds. Isolates characterized as Xanthomonas species tested negative for the Gram reaction, negative for anaerobic growth, negative for fluorescent pigment test, positive in YDC and was negative to urease test. The Bacillus species was Gram positive, spores stained green on microscopic examination at $40 \mathrm{X}$ (positive) and tested negative for anaerobic growth.

\section{Morphological features of fungal pathogens after culture and isolation}

Isolates of BT showed greyish to black colour on PDA with abundant mycelia which were 
fast growing with zonations (Plate 2A). The conidia had thick cell walls that were hyaline, unicellular and oblong in shape and when mature, they looked dark brown, pigmented and uniseptate. The colony of Cercospora $\mathrm{sp}$ (CER) on PDA was a uniform dark green growth. It has long conidiophores that arose from the stroma, septate was unbranched and multigeniculate (Plate 2B). The characteristic morphological features of Collectotrichum gleosporiodes (CG) were uniformed conidia, hyaline, cylindrical with both ends rounded and with good sporulation (Plate 2C). On PDA, Corynosporium sp.(COR) appeared as effuse grey to light olivaceous green which turns later to brown and dark brown and hairy. Conidia were in chains and variable in shape (straight, cylindrical and curved) (2D). The colony of Curvularia lunata (CL) on PDA was generally black with three distinct zones. The mycelia were abundant and septate and the conidia four celled with pale end walls (Plate 2E). Banana shaped Fusarium oxysporium (FO) had the microconidia with mainly three septa and foot shaped at the basal end. The microconidia were uniformed and their microconidia were elongated and two celled (Plate 2F). Fusarium verticillioides (FV) that was banana shaped had aerial conidium that was septate, single celled and in chains (Plate 2G). The presence of white button kind structure which becomes doomed shape on the stem of the plant and rot that turns to make a hollow on the lower and or on the upper part of the stem of plants infected with Ganoderma boninense (GB). were the first signs of infection (Plates 1D and 1E; Plate 2H). The colony of Penicilium species was greenish with hyphae that is septate, conidiosphore was simple and sometimes branched, phialides were long and pointed and conidia was unicellular, round, pigmented and in chains (Plate 2I) Trichoderma sp. showed a fast growing colony that was at first white in colour and later became yellowish green. It had loosely arranged conidia and the phialides were ellipsoidal (Plate 2J). In all, 13 microoorganisms were associated with disease oil palms out of which 10 were fungi and 3 bacteria. Fusarium oxysporium was the most frequently isolated microorganism in Kokundu (21 out of 60) and 11 out of 60 for Lipenja while Bacillus cereus was the most common bacterium identified ( 8 in Kokundu and 13 in Lipenja) (Table 1). Corynosporiun sp. and Trichoderma sp. were absent in Kokundu while BT and Cercospora sp. were present in Lipenja (Table 1). Fungal disease incidence ranged between $3.3 \%$ to $35 \%$ in Kokundu and $5 \%$ to $21.6 \%$ in Lipenja with Fusarium oxysporium having the highest incidence among the microorganisms in both locations (35\% and $18.3 \%$ for Kokundu and Lipenja respectively). Lipenja was more infected with Bacillus cereus (21.6\%) as against Kokundu with $13.3 \%$ (Table 2). Mixed occurrence of microorganisms was noted in 22 disease samples, with 17 having 2 (11 in Kokundu and 6 in Lipenja) while 5 had 3 each (3 I Kokundu and 2 in Lipenja) (Figures 2 and 3). Latent infection with BT, Curvularia sp. and Bacillus substilis was noticed in 5 out of 20 asymptomatic samples. BT, Cercospora sp. were absent in Lipenja fields while Trichoderma sp. and Corynespora sp. were not detected in Kokundu

In this study, 13 microorganisms were isolated from oil palm diseased plants, some are known to have pathogenic effects to their host, animals and humans such as Fusarium oxysporium, Fusarium venticillioides, Ganoderma boninense, Penicillium sp. (Mih and Tonjock, 2015; Linawita et al., 2016)

Fusarium wilt disease of the oil palm caused by Fusarium oxysporium was the most prevalent disease of the oil palm. Incidence ranged between $3.3 \%$ to $26.6 \%$ with plantations in Kokundu being more infected (26.6\%) than those of Lipenja (13.3\%). The higher incidence of this disease in Kokundu may be because the plantings in this locality 
were older $(<13$ years $)$ than those of Lipenja which were about 7 years. It is likely that there was more build-up of pathogen inoculum and spread in Kokundu than Lipenja. Also, younger plants in Lipenja may imply newer genotypes that are less susceptible to Fusarium oxysporium infection (Koussinou et al., 2019).

This result is in compliance with earlier report by Tonjock and Mih (2015) which stated that vascular wilt is the most serious disease of the oil palm in West and Central Africa particularly Cote d'Ivoire, Benin, Nigeria, Democratic Republic of Congo and Cameroon and can cause up to $70 \%$ mortality in plantations. Tengoua and Bakoume (2008) reported that this disease is one of the most important in the South West Region of Cameroon. The implication of this result is that these sites harbour spread strains of the pathogen and also that the plant materials are susceptible to vascular wilt. It was also observed during the field survey that not all the plants in a site showed symptoms of vascular wilt disease which are dehydration of the lower leaves, facture of the spines by onethird from the petiole, slow growth and yellowing of the young leaves. Dry leaves fall and the young palm emits 2-4 arrows which opens slowly (De Franqueville and Diabate, 1995). This may be as a result of variability in the expression of vascular wilt and also, could be due to differential response of the same gene cluster or to the expression of different genes especially as plant material at the survey site was uniform. It could also be that the development of infection is conditioned by the interaction between pathogen and host susceptibility genes (Koussinou et al., 2019).

Basal stem rot disease of the oil palm caused by the white rot fungus, Ganoderma boninense is another disease of importance identified in the oil palm fields in Ndian Division. In South East Asia, basal stem rot is one of the major obstacles in oil palm cultivation and an emerging disease in West and Central Africa (Linawita et al., 2016). Typical symptoms of BSR disease include unopened spear leaves, bassidiocarp formation, bole creation and plant death. Sandy soils have been reported to enhance pathogen development (Mih and Bakoume, 2015; Koussinou et al., 2019)). There was high incidence of BSR disease $(6.6 \%$ in Kokundu and $5.8 \%$ in Lipenja). This is in line with studies carried out by Mih and Tonjock (2015) who reported incidence of 5.4\%-39\% in the plantations of the Cameroon Development Corporation (CDC), one of the major oil palm agro-industries in the country. There was not much disparity in soil type between the two areas surveyed which may be the reason why disease incidence was not quite different.

Colletotrichum gleosporioides that is a major disease in oil palm nursery seedlings and has been reported to cause moderate to severe damage in wide areas of Central and South America (Chinchilla and Escobar, 2007), was isolated and identified from survey samples with incidence of $14.1 \%$ (11.6 for Kokundu and 16.6 for Lipenja). This organism produces leaf spots on oil palm leaves especially on the younger plants than the older ones. As leaf matures, older leaves become more resistant to the disease such that the rate of lesion expansion slows but with adequate moisture, new spots continue to form resulting in larger older spots with black edges surrounded by numerous small spots and flecks. Typical spots are 5-10mm long and brown to grey with dark brown to black borders. The involvement of $C$. gleosporioides to pathogenicity is yet to be fully established in several works even though it is known that the organism is saprophytic (non-pathogenic).

Uchidi (1997) reported association of leaf spots from many palm growing areas of the world and Colletotrichum was isolated from them still it was not implicated as the cause of 
the leaf spot.

Curvularia leaf blight (CLS) caused by Curvularia lunata is a common and minor disease problem in oil palm production even though it can spread rapidly in oil palm growing areas (Chaninun et al., 2013). Incidence of this disease was $8.1 \%$. Lipenja was free of this organism as no sample collected was identified to harbour this pathogen. This may be because more attention is put in disease management in Lipenja because of its younger plantings than Kokundu. Cercospora leaf spot disease caused by Cercospora elaeidis is the most widespread foliar disease in the nursery seedlings and young oil palms in West Africa but of minor importance to the oil palm (Kittimorakul et al., 2013). Symptoms of CLS include appearance of small yellow spots on the leaves that starts from light brown and later changing to dark brown, covering almost all the parts of the leaves and finally the infected leaves turn black. Incidence of this disease in both fields was $6.6 \%$ and $0.0 \%$ for Kokundu and Lipenja respectively). This difference might be due to delayed management of the disease in Kokundu that led to its build-up.

Table.1 Distribution of fungal and bacterial microorganisms isolated from oil palm samples collected from Kokundu and Lipenja Divisions of Pamol Plantations.

\begin{tabular}{|c|c|c|c|c|}
\hline S. No. & $\begin{array}{l}\text { Microorganisms } \\
\text { identified in the } \\
\text { survey }\end{array}$ & $\begin{array}{c}\text { No. of } \\
\text { pathogens } \\
\text { identified in } \\
\text { Kokundu }\end{array}$ & $\begin{array}{l}\text { No. of microooganisms } \\
\text { identified in Lipenja }\end{array}$ & $\begin{array}{c}\text { Total no. of } \\
\text { microorganisms } \\
\text { identified in survey } \\
\text { samples }\end{array}$ \\
\hline \multicolumn{5}{|l|}{ FUNGI } \\
\hline 1 & $\begin{array}{c}\text { Botryodoplodia } \\
\text { theobromae }\end{array}$ & 5 & 0 & 5 \\
\hline 2 & Cercospora sp. & 4 & 0 & 4 \\
\hline 3 & $\begin{array}{l}\text { Collectotrichum } \\
\text { gleosporiodes }\end{array}$ & 7 & 10 & 17 \\
\hline 4 & Corynesporium sp. & 0 & 4 & 4 \\
\hline 5 & Curvularia lunata & 5 & 0 & 5 \\
\hline 6 & Fusarium oxysporium & 21 & 11 & 32 \\
\hline 7 & $\begin{array}{c}\text { Fusarium } \\
\text { verticillioides }\end{array}$ & 12 & 7 & 19 \\
\hline 8 & $\begin{array}{l}\text { Ganoderma } \\
\text { boninense }\end{array}$ & 3 & 4 & 7 \\
\hline 9 & Penicillium sp. & 2 & 3 & 5 \\
\hline \multirow[t]{2}{*}{10} & Trichoderma sp. & 0 & 4 & 4 \\
\hline & Total & 59 & 43 & 102 \\
\hline \multicolumn{5}{|l|}{ BACTERIA } \\
\hline 12 & Bacillus cereus & 10 & 13 & 23 \\
\hline 11 & Bacillus substilis & 11 & 5 & 16 \\
\hline \multirow[t]{2}{*}{13} & Xanthosomas sp. & 3 & 4 & 7 \\
\hline & Total & 24 & 22 & 46 \\
\hline
\end{tabular}


Table.2 Incidence of the microorganisms identified on oil palm disease samples from Kokundu and Lipenja

\begin{tabular}{|c|c|c|c|c|}
\hline Serial No & Microorganism & $\begin{array}{c}\text { \% incidence in } \\
\text { Kokundu } \\
\text { FUNGI }\end{array}$ & $\begin{array}{c}\text { \% incidence in } \\
\text { Lipenja }\end{array}$ & $\begin{array}{c}\text { \% overall } \\
\text { incidence }\end{array}$ \\
\hline $\mathbf{1}$ & $\begin{array}{c}\text { Botryodoplodia } \\
\text { theobromae }\end{array}$ & 8.3 & 0.0 & $\mathbf{4 . 1}$ \\
\hline $\mathbf{2}$ & $\begin{array}{c}\text { Cercospora } \text { sp. } \\
\text { Collectotrichum } \\
\text { gleosporiodes }\end{array}$ & 6.6 & 0.0 & $\mathbf{3 . 3}$ \\
\hline $\mathbf{3}$ & Corynesporium sp. & 0.0 & 16.6 & $\mathbf{1 4 . 1}$ \\
\hline $\mathbf{4}$ & Curvularia lunata & 8.3 & 6.6 & $\mathbf{3 . 3}$ \\
\hline $\mathbf{5}$ & Fusarium oxysporium & 35 & 18.0 & $\mathbf{4 . 1}$ \\
\hline $\mathbf{6}$ & Fusarium verticillioides & 20 & 8.3 & $\mathbf{2 6 . 6}$ \\
\hline $\mathbf{7}$ & Ganoderma boninense & 5 & 6.6 & $\mathbf{1 4 . 1}$ \\
\hline $\mathbf{8}$ & Penicillium sp. & 3.3 & 5 & $\mathbf{4 . 1}$ \\
\hline $\mathbf{9}$ & Trichoderma sp. & 0.0 & 8 & $\mathbf{3 . 3}$ \\
\hline $\mathbf{1 0}$ & & BACTERIA & & $\mathbf{1 7 . 5}$ \\
\hline $\mathbf{1 2}$ & Bacillus cereus & 13.3 & 21.6 & $\mathbf{1 3 . 3}$ \\
\hline $\mathbf{1 1}$ & Bacillus substilis & 18.3 & 8.3 & $\mathbf{5 . 8}$ \\
\hline $\mathbf{1 3}$ & Xanthosomas sp. & 5 & 8 & \\
\hline & & & & \\
\hline
\end{tabular}

Fig.1 (A) Map of Cameroon, (B) South West Region and (C) Ndian Division where Pamol Plantations is located.

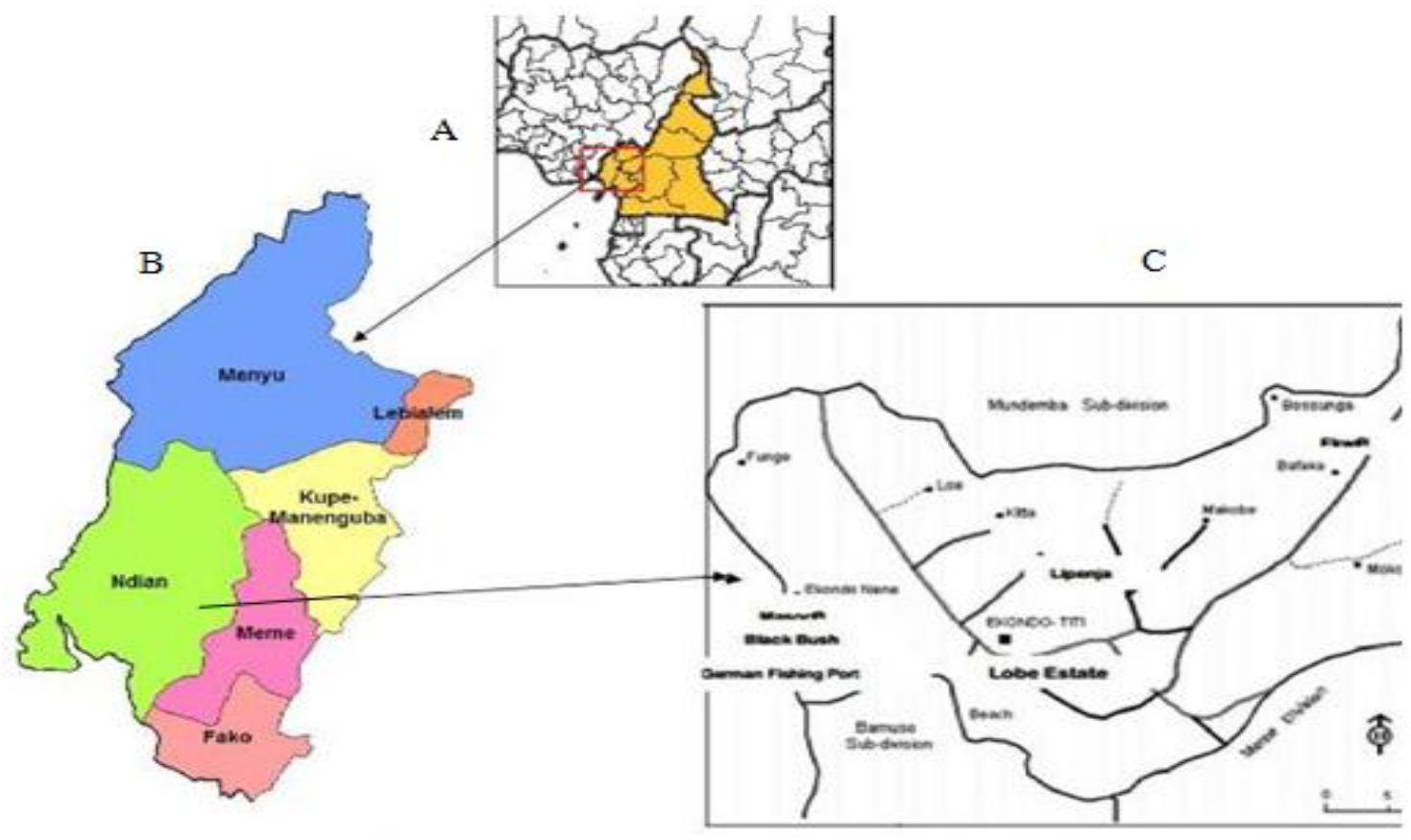

Source: Kimengsi and Lambi, 2015 
Fig.2 Number of samples mixedly infected with 2 and 3 microorganisms in Kokundu and Lipenja plantations.

[ KOKUNDU

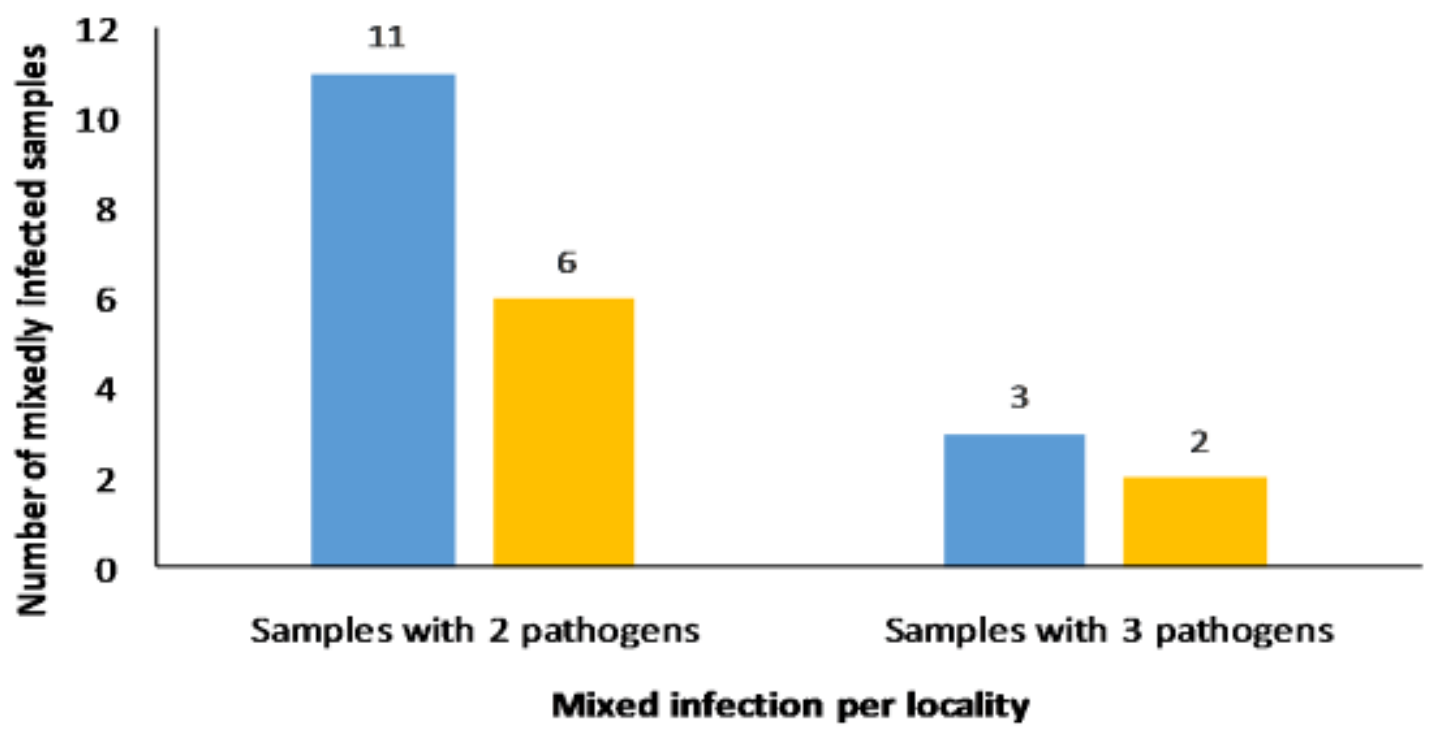

Fig.3 Different microorganism types per sample collected from kokundu and Lipenja plantations.

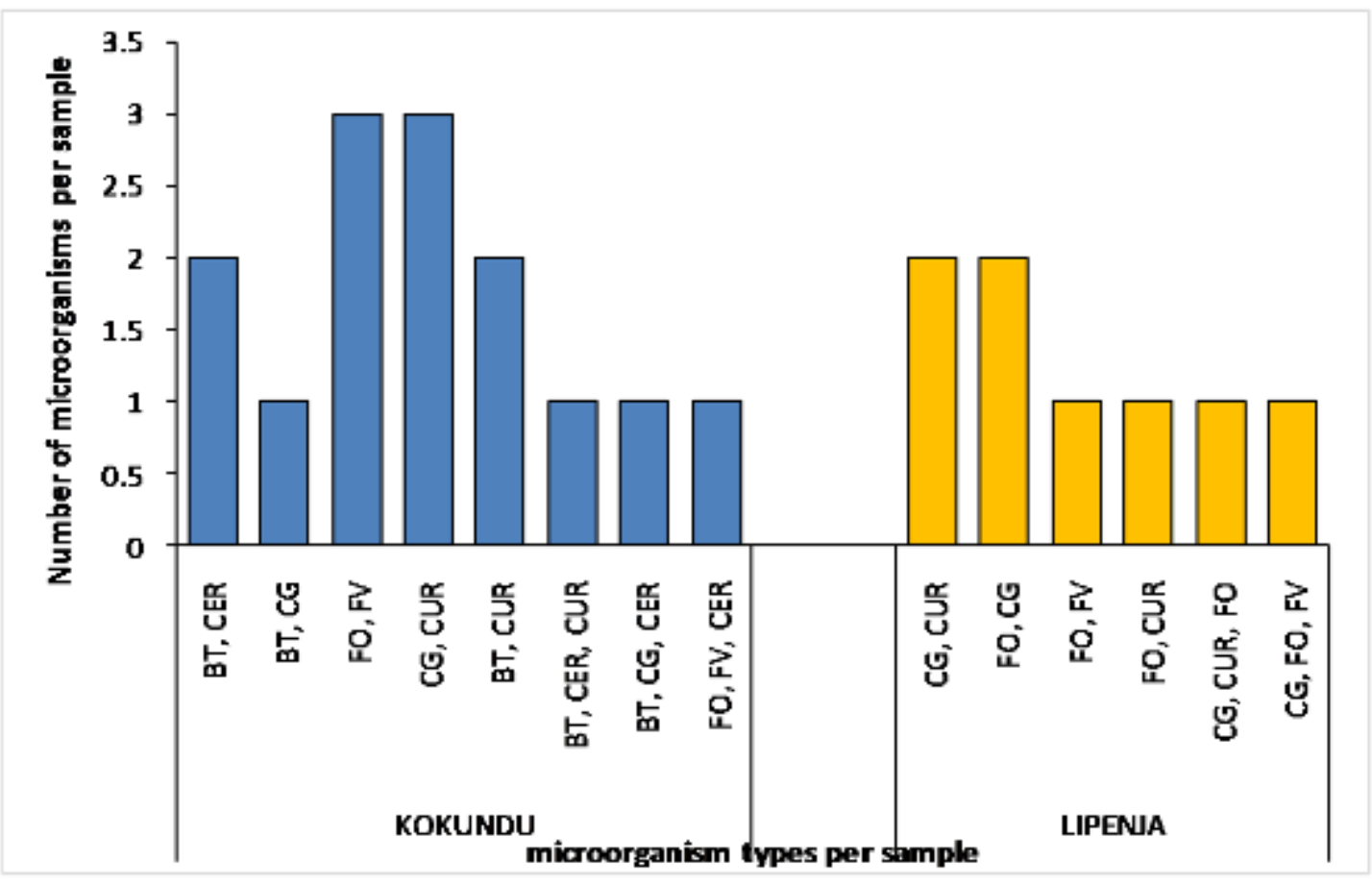


Plate.1 Foliar and stem symptoms of diseased plants.
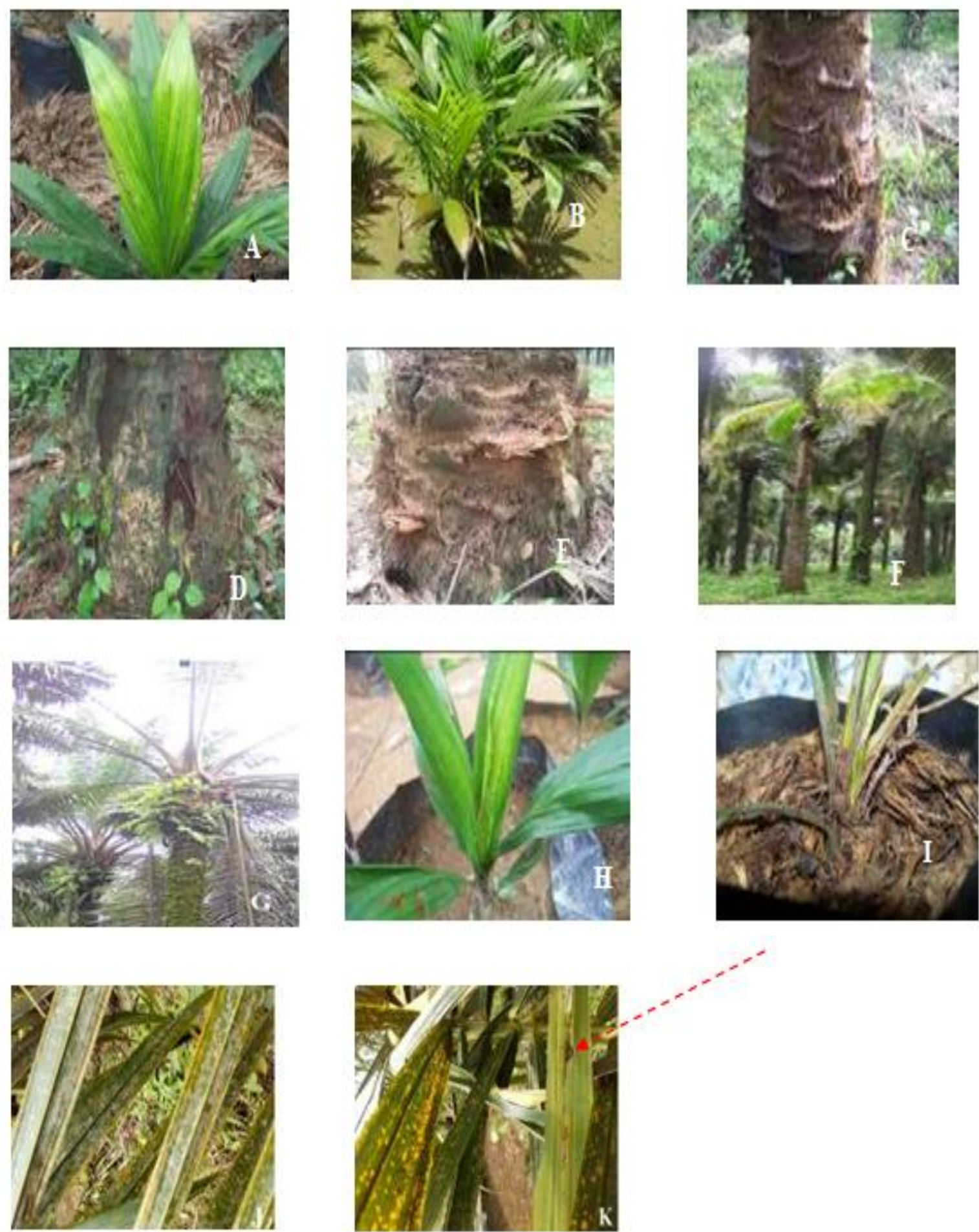

$\mathrm{A}=$ mosaic $; \mathrm{B}=$ brown spots; $\mathrm{C}=$ slimy $/$ rotted stem; $\mathrm{D}=$ basal stem rot $; \mathrm{E}=$ Fruiting bodies on stem; $\mathrm{F}=$ yellowing of leaves and wilting; $\mathrm{G}=$ Bud rot/ spear rot; $\mathrm{H}=$ Chlorosis; $\mathrm{I}=\mathrm{Rot}$; $\mathrm{J}=$ Leaf discolouration/ brown leafspots; $\mathrm{K}=$ Black leafspots 
Plate.2 Microorganisms isolated from diseased plant tissues and their associated colonies grown on PDA
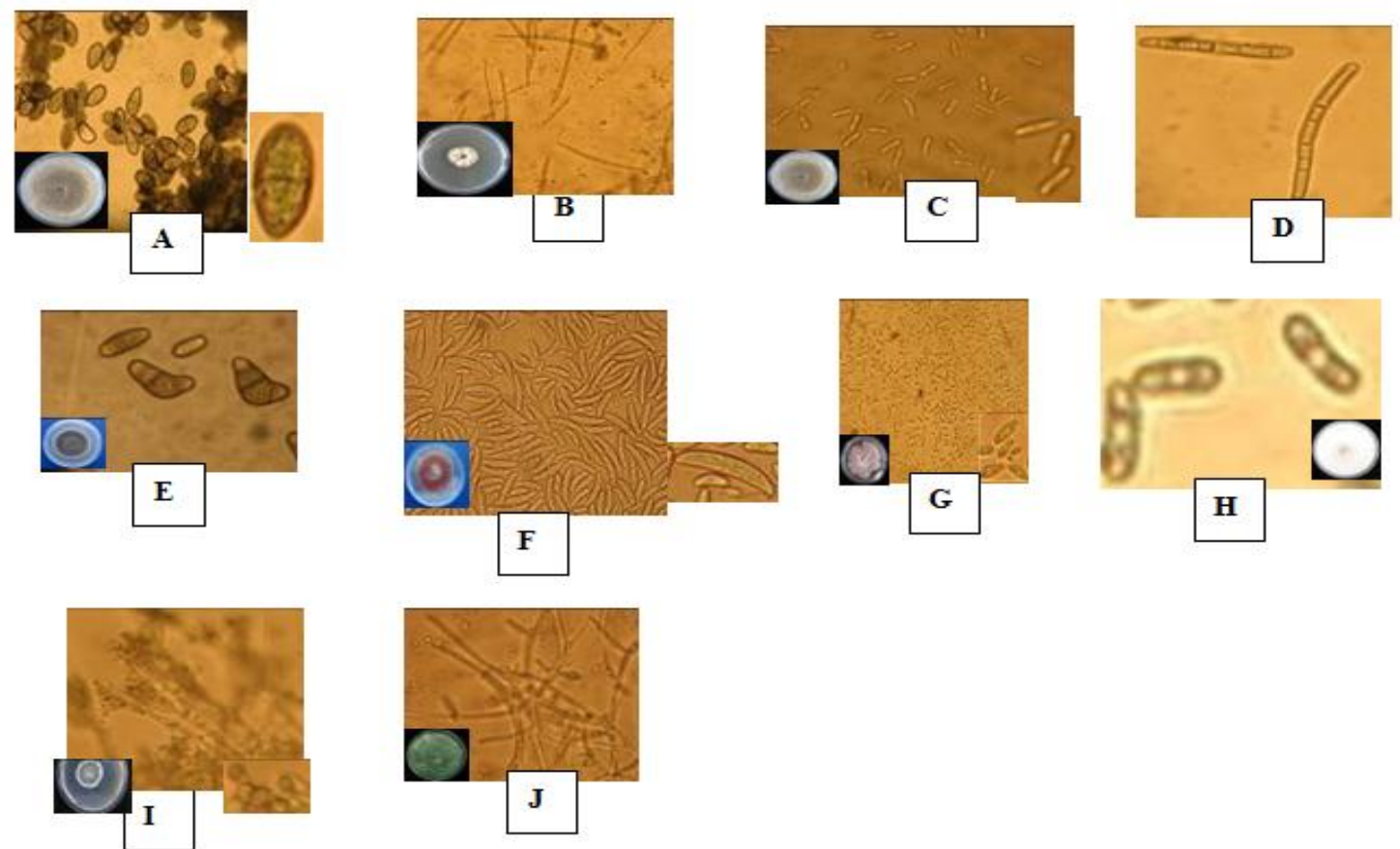

$\mathrm{A}=$ Botryodiplodia theobromae $; \mathrm{B}=$ Cercospora $\mathrm{sp} ; \mathrm{C}=$ Collectotrichum gleosporoides $; \mathrm{D}=$ Corynosporium $\mathrm{sp}$;

$\mathrm{E} .=$ Curvularia lunata $; \mathrm{F}=$ Fusarium oxysporium $; \mathrm{G}=$ Fusarium verticilioides $; \mathrm{H}=$ Ganoderma boninense $; \mathrm{I}=$ Penicillium sp. $\mathrm{J}=$ Trichoderma sp.

Bacillus cereus was the most abundant bacteria isolated from samples with incidence of $21.6 \%$ in Lipenja and $13.3 \%$ in Kokundu. The presence of bacteria on the oil palm has been reported by several authors (Syafig et al., 2021; Ahasanul et al., 2019) but they have little or no direct pathogenic effect on plant. However, Bacillus cereus has been reported to increase growth of the aerial parts of the oil palm seedling and in combination with Trichoderma sp., they are capable of producing Idole Acetic Acid which is a plant growth promoter. Their combinations also, improve plant resistance to pests/ diseases. $B$. cereus has been used in the cultivation of palm oil mill effluent which is a technique to attain high biomass growth and lipid production (Syafiq et al., 2021). Ahasanul et al., (2019) reported that B. cereus and Pseudomonas sp. are used to degrade used cooking oil which is an important environmental pollutant.

10 fungal and 3 bacterial microorganisms are associated with the oil palm in Ndian Division of Cameroon. Among them, Fusarium oxysporium, Ganoderma boninense and Collectotrichum gleosporioides are of major pathogenic importance to the crop. There is need for an extensive survey to be carried out to understand the extent of infection of these pathogens so that a holistic approach to managing them can be carried out. The Ministry of Agriculture and Rural Development should delegate extension agents to oil palm producing areas in Cameroon to give advice on preventive measures of managing these diseases.

\section{Acknowledgement}

The authors wish to thank the management of Pamol Plantations Plc for providing personnel who took us to the various plantations and enlightened us on the history of the company. 


\section{References}

Afui Mathias Mih, Tonjock Rosemary Kinge (2015) Ecology of basal stem rot disease of oil Palm (Elaeis guineensis Jacq.) in Cameroon. American Journal of Agriculture and Forestry 3 (5): 208215.

Ahasanul Karim M, Amirul Islam, Abu Youssuf M D, Maksudur Rahman Khan, Cheku Mohammad Faizel (2019) Microbial lipid accumulation through bioremediation of palm oil mill waste water by Bacillus cereus. ACS Sustainable Chemistry and Engineering DOI: $\quad 10.1021$ acsuschemeng.9b01960

Aiman Nabilah Noor Azmi, Siti Khairunniza Bego, Mahirah Jahari, Ferrah Melissa, Ian Yule and Nur Azuan Husin (2020). Early detection of Ganoderma boninense in oil palm seedlings using support vector machines. Remotesensing 12(23): 3920

Amsalu Abera (2016). Morphological characteristics of Colletotrichum species associated with mango (Mangifera indica) in Southwest Ethiopia. Food Science and Quality Management 48: 2224-2225

Ariffin, D. (1994). Current status of Ganoderma research in PORIM. In: First International Workshop on perennial crop diseases caused by Ganoderma. 28 November - 3 December 1994, Serdang, Malaysia. CAB International, Wallingford, UK

Arrifin, D., Idris A S, Marzuki A. (1996). Spread of Ganoderma boninense and vegetative

compartibility studies of a single field palm isolates. In Proceedings of the 1996 PORIM Oil palm Congress (Agriculture), September 1996. Edited by Ariffin et al., PORIM, Bangi, Selangor, Malaysia. 317-329p
Bennett, J. W. and Klich, M. (2003). Mycotoxins. Clinical Microbiology Review 16: 497-516

Chinchilla, C. and Escobar, R. (2007). Red ring and other diseases of the oil palm in Central and South America. Associate consultant ASD, Costa Rica. ASD Oil Palm Papers No. 30, 1-13p

Chininun Pornsuriya, Anuraq Sunpapao, Nathapach Srihanant, Kanyapak Worrapatamasri, Jittra Kittimorakul, Supaporn Phithakkit and Vasun Patcharat (2013). A survey of diseases and disorders in oil palm of Southern Thailand. Plant Pathology Journal 12 (4): $169-175$

Claudine K S Laurentine Koussinou, Appolinaire Adandonon, Leifi Nodichao (2019).

Distribution and incidence of Fusarium Wilt in oil palm in Benin, Journal of applied Biosciences 235: 13831-13839

Dominguez-Guererro, Ilka, P., MohalliCastillo, Sari, R., marin-Montayo, Mauricio, A. and Pino-Menesini, Henry, B. (2012). Characterization and genetic variability of Colletotrichum gleosporioides sensu lato in oil palm (Elaeis guineensis Jacq) in plantations in Venezuela. Tropical Plant Pathology 37 (2): 108-122

Dubos, B., Baron, V., Bonneau, X., Dassou, O., Flori, A., Impiens, R. (2019). Precision agriculture in oil palm plantations. Diagnostic tools for sustainable Nitrogen and Potassium supply.oil seeds. Fats, Crop Lipids 26 (1): $1-8$

Franqueville, H. de and Diabate, S. (2004). Status of Oil Palm Vascular Wilt. MPOB.

International Conference on Pests and Diseases of Importance to the Oil Palm Industry. 18 - 19 May, 2004, Kuala Lumpur, Malaysia. 30-36p.

Fravel, D, Olivain, C. and Alabouvette, C. 
(2003). Fusarium oxysporium and its biological control. New Pathologist 157 (3): 493-502

Gerhardt, P. (1981). Manual of Methods of General Microbiology. American Society of Microbiology, Washington DC, USA. 72p

Xing, F., H. Hua, JN Salvarey, Y. Zhao, L. Zhou, X. Lui (2014). Growth inhibition and

morphological alteration of Fusarium oxysporium by Cinnamon oil and Cinnamaldehyde. Food Control 46: 343-350

Gate Fe Chung (2012). Effects of pests and diseases on oil palm yield. Palm Oil Production,

Processing, Characterization and Uses. DOI: 10.1016/ B978-0-98189. 36-9-350009-5

Helene Adam, Stefan Jouannic, Jacques Escoute, Yves Duval, Jean Luc Vermeil and James Tregear (2005). Reproductive developmental complexity in the African oil palm (Elaedis guineensis, Arecaceae). American Journal of Botany 92 (11): 1836-1852

Herdis, Herdiansyah, Habibullah, Adi Negoro,Nurul Rusdayanti and Siti Shara (2020). Palm oil plantation and cultivation. Prosperity and Productivity of small holders. Open Agriculture 20 (5): 617-630

Idris, A. S. and Ariffin, D. (2004). Basal Stem Rot. Biology, Detection and Control. MPOB. International Conference on Pests and diseases of Importance to the Oil Palm Industry. 18 - 19 May, 2004, Kuala Lumpur, Malaysia. 34p.

Jude Ndzifon Kimengsi and Cornelius Mbifung Lambi (2015). Reflections on the natural resource development paradox in the Bakassi area (Ndian Division) of Cameroon. Academic Journals 7 (9): 239-249
Kinge, T. R., Mophorcha, Z. L. and Mih, A. M. (2019). Cultural variability of Fusarium

oxysporium f. sp. elaeidis isolates from oil palm in Southwest Region and sensitivity to four plant extracts. Plant Pathology and Quarantine 9 (11): 116127

Kittimorakul Jittra, chaninun Pornsiruija,Anura Sunpapao, Vasun Petcherat (2013). Survey and incidence of leaf blight and leaf spot diseases of oil palm seedlings in Southern Thailand. Plant Pathology Journal 12: 149-153

Koussinou, Claudine, laurentine, K.S., Appolinnaire Adandonen and Leffi, Nodichao (2019). Distribution and Incidence of Fusarium oxysporiu in the oil palm of Benin. Journal of Applied Bioscience 135: 13831-13839

Leslie, J. F. and Summerell, B. (2013). An Overview of Fusarium. In: Fusarium

Genomics. Molecular and Cell Biology. D. W. Brown and R. H. Proctor eds. Caister Academic Press, Norfolk, UK. 1-9p

Lisnawita, H., Hanun, J., Tantawi, A. R. (2016).A survey of basal stem rot disease of the oil palm (Elaeis guineensis Jacq) in Kebun Bukit Kijang, North Sumatira, Indonesia. In $2^{\text {nd }}$ International Conference on Agriculture and Bioscience (ABS) (2016) Conference Series, Earth and Environmental Science 41 (2016) 012007. 23-26 July 2016, Shanghai, China

Malaysian Oil Palm Council (MPOC) (2019). Annual Report No. 2, Jalan Section 51A 46100 Petaling Jaya Selangor, Malaysia

Mohammed Manjur Shar and Hamisu Afiya (2019). Identification and isolation of

Trichoderma sp. Their significance on Agriculture. Human health, Industrial and Environmental Application: In 
Trichoderma-The Most Widely Used Fungicide. 13pp

Ntsomboh-Ntsefong Godswill, Epoh-Nguea Toussaint, Madi-Galina, Nsimi-Mva Almandi, Ngando Ebongue Georges, Frank Kounga, Tagne Samuel, Mpodo Mpondo Emmanuel and Dibong Didier (2019). Isolation and in-vitro characterization of Fusarium oxysporium $\mathrm{f}$ sp. elaedis causal agent of oil alm (Elaedis guineensis Jacq) vascular wilt. Research in Plant Sciences 3 (1): 18-26

Ordway, E. M., Rosamond, 1. Naylor, Nkongho, R. N., Lambin, E. F. (2019). Oil palm

expansion and deforestation in South West Cameroon associated with proliferation informal mills. Nature Communications 108: 14

Probst, C., Njapau, H. and Cotting, P.I. (2007). Outbreak of an acute aflatoxicosis in Kenya in 2004. Identification of the causal agent. Applied Environmental Microbiology
73: $2762-2764$

Tengoua, F. F.and Bakoumé C. (2008) Pathogenicity of Cameroon strains of Fusarium

oxysporum f. sp. elaeidis-The causal agent of oil palm vascular wilt. The Planter 84 (985): 233-237

Tuan Hassan Tuan Mohammed Syadiq, Syd Ali Nusabati and Mohd Yusap Rafii (2021). A novel strategy for oil palm millers. Petanika Journal of Tropical Agricultural Science 44 (16): 157-170

Uchida, Y. Janice and Chris, Y. kadooka (1997). Colletotrichum leaf spot of Red sealing

wax palm. Cooperative Extension Services. College of Tropical Agriculture and Human Resources, University of Hawaii, Manoa. 105p

Yvonne K. Nchanji, Raymond N. Nkongho, William A. Mala and Patrice Levang (2016). Efficacy of oil palm intercropping by smallholders. Case of Southwest, Cameroon. Agro-forestry Systems 90: 509-519.

\section{How to cite this article:}

Oben, T. T., O. Oguntade, A. E. Egbe, A. A. Mbah, and Becke, H. I. 2021. Evaluation of Bacterial and Fungal Diseases of the Oil Palm (Elaeis guineensis Jacq) in Pamol Plantations, Ndian Division, Southwest Region, Cameroon. Int.J.Curr.Microbiol.App.Sci. 10(07): 200-215. doi: https://doi.org/10.20546/ijcmas.2021.1007.022 